\title{
Jesus: en falleret bonderomantiker?
}

\author{
En reviewartikel af Per Bilde, Hvor original var Jesus?,
}

København, Anis 2011. 348 sider. Pris 348 d.kr.

ANDERS KLOSTERGAARD PETERSEN

Per Bilde har et imponerende, overvejende dansksproget forfatterskab bag sig, når det gælder rekonstruktionen af den historiske Jesus. Utrættelig pauker han sin pointe ind, at forskningen i den historiske Jesus i Danmark fortsat er sørgelig forsømt. Derfor er det også hæderfuldt, at han med en beundringsværdig arbejdsindsats i de seneste omtrent ti år har gjort netop dette felt til et af sine største forsknings- og publikationsaktiver. Når det så er sagt, må man imidlertid også konstatere, at der trods Bildes besværgelser om det modsatte er tale om et betydeligt element af gentagelser i bøgerne En religion bliver til. En undersøgelse af kristendommens forudsætninger og tilblivelse indtil år 110 fra 2001, Den historiske Jesus fra 2008, og senest Hvor original var Jesus? Selvfølgelig kan man som Bilde fremhæve udvikling i forståelse, anderledes vægtning, etc.; men det ændrer ikke ved, at der er betydelige overlap mellem bøgerne. Det gælder i henseende til både overordnet forståelse og tekstanalyser.

Den foreliggende bog er skrevet i et tilgængeligt sprog, som gør den anvendelig i både undervisningssammenhæng og for et bredere publikum. Når det så er sagt, må det også tilføjes, at der i bogen optræder flere knudrede formuleringer, der strækker sig over adskillige sætninger, inden man når et forløsende punktum (se fx flere af citaterne nedenfor). Foruden et forord består bogen af seks kapitler, hvoraf det første har en indledende karakter, mens det afsluttende udgør bogens relativt korte konklusion (otte og en halv sider). De øvrige kapitler drøfter Jesus-forskningen fra omtrent 1770 frem til 2010 (kap. 2), tidligere tolkninger af Jesus' originalitet (kap. 3), Jesus' eskatologiske projekt (kap. 4), og endelig i det mest omfattende kapitel (lidt over 100 sider), hvad Bilde betegner den komparative Jesus (kap. 5). Det drejer sig om sammenligninger mellem Bildes rekonstruerede, historiske Jesus og andre skikkelser fra både samtiden og senere perioder. Bogen er endelig forsynet med en omfattende litteraturfortegnelse, der rummer de væsentligste større bidrag i diskussionen om den historiske Jesus, ligesom den indeholder et tekstregister og en kort og 
koncis oversigt over centrale historiske og eksegetiske fagudtryk. Der forekommer ikke mange fejl i bogen; men nogle er der. Fx hævdes det, at Reimarus' Fragmente des wolfenbüttelschen Ungenannten først blev udgivet længe efter forfatterens død; men Lessing udgav dem såmænd i 1774-78 og Reimarus døde blot seks år tidligere i 1768 (s. 42). E.P. Sanders gøres til brite, skønt han er fra Texas (s. 52). Joseph Ratzinger gøres til Pius XII, men han var altså Benedikt XVI (s. 10). Thomas Kazen er fejlagtigt skrevet med apostrof s. 106, men ikke i litteraturlisten s. 323. Damaskusskriftet er ikke ret beset ikke et Qumran-skrift, men stammer fra en Geniza i Kairo, om end det har en række nære paralleller med fragmenter fundet i Hule 4 i Qumran (s. 109). Konstantinopel var en periode Osmannerrigets hovedstad, men ikke den ottomanske hovedstad (s. 275), ligesom det tyrkiske imperium var osmannisk og ikke ottomanisk (s. 291). Hurtardo 2003 er fejlplaceret i litteraturlisten (s. 322). Mindre trykfejl optræder s. 166.170.253.

Der er mange værdifulde ting i Bildes bog. Det gælder ikke mindst hans forsøg på at tolke Jesus-skikkelsen i sammenhæng med en række figurer, man møder hos Josefus, om end andre internationalt har gjort det samme (se fx Rebecca Gray, Prophetic Figures in Late Second Temple Jewish Palestine: The Evidence from Josephus, Oxford, Oxford UP 1993, som netop fremhæver betydningen af vidnesbyrdene hos Josefus for en forståelse af den historiske Jesus). Her er der imidlertid ikke så meget nyt at komme efter, da det ikke mindst var netop brugen af Josefus i sammenhæng med forsøget på at rekonstruere den historiske Jesus, der også udmærkede Bildes to tidligere bøger om emnet. Omvendt må man prise bogen for på relativ beskeden plads at give en udmærket diskussion af den historiske Jesus inden for rammerne af et bestemt forskningsparadigme, se nedenfor. Bogens fortjeneste ufortalt rummer den imidlertid også en række problemer, af både eksegetisk, historisk, metodisk og teoretisk karakter. Bildes monografi En religion bliver til har allerede været genstand for diskussion i $R v T .{ }^{1}$ Men da den tidligere drøftelse i højere grad har været rettet mod hans rekonstruktion af den tidlige kristendom og ikke så meget hans forsøg på at rekonstruere den historiske Jesus, er der grund til at opholde sig mere udførligt ved dette emne dels fordi det i kraft af sin vigtighed fortjener en selvstændig behandling, dels fordi Bilde tydeligvis opfatter sig selv og sin forskning i den historiske Jesus som offer for en "ideologisk, apologetisk tendens" blandt danske nytestamenteforskere (se ikke mindst s. 80-83). Det synes jeg er en urimelig anklage, som jeg en gang for alle gerne vil bidrage til at mane i jorden.

Bilde har selv ved flere lejligheder og også i den aktuelle bog understreget, hvordan han oplever at stå isoleret i en dansk forskningssammenhæng, når det gælder interessen for den historiske Jesus. ${ }^{2}$ Det har han nok ret $i$; men til gengæld kan man så også konstatere, at han kun i meget ringe omfang forstår, hvorfor en lang række

\footnotetext{
Se Carsten Breengaards anmeldelse af Per Bildes En religion bliver til i RvT 41, 2002, 104-110.

Se Per Bilde "Dialog mellem narrativ og historisk eksegese," RvT 24, 1994, 79-90, og Ole Davidsen "Faktor - tekst - funktion. Et svar til Per Bilde," i samme nummer s. 91-107.
} 
forskere fortsat er meget tilbageholdende, grænsende til det pointeret skeptiske, når det gælder rekonstruktionsforsøg af den historiske Jesus. Her forfalder Bilde i bogen desværre til psykologiseringer og fraviger efter min mening en saglig diskussion. I stedet for at tage de pågældendes argumenter for pålydende og tage livtag med dem hævder Bilde - uden at fremføre dokumentation for påstanden - at denne tilbageholdenhed over for at rekonstruere den historiske Jesus udspringer af en ideologi, der hidrører fra dialektisk teologi; men "som de pågældende eksegeter dog selv foretrækker at karakterisere med de mere sympatiske betegnelser: 'teoretisk', 'metodologisk' og 'hermeneutisk'” (s. 83). Hvis det er udgangspunktet for drøftelsen, er det mere end vanskeligt at indlade sig på diskussion med Bilde, som forfalder til patosfuldt sprog og mistænkeliggørelse, men ikke er i stand til at fremføre argumentation for sin sag. Jeg finder det fx patetisk, når Bilde iscenesætter sig selv som den i en dansk kontekst miskendte martyr, som på historieforskningens vegne kæmper en sandhedskamp over for teologiske eksegeter (jf. s. 82-85). Det er en både billig og fordrejet form for argumentation. Hvorfor ikke i stedet anerkende, at der inden for historievidenskaben eksisterer forskellige metodiske tilgange med hver deres teoretiske hjemmel, hvis plausibilitet i forhold til et bestemt kildemateriale må drøftes i sag for sag? Det havde været sagligt.

Hos Bilde spilles der imidlertid på en anden boldgade. Eksempelvis får man at vide, at såvel den konstruktivistiske som den postmodernistiske periode, der også har haft deres sørgelige virkning på Jesus-forskningen, nu er et overstået kapitel blot. På ny er det "atter blevet god tone at tale om 'sandt' og 'falsk' i humaniora og i historisk forskning" (s. 85). Jeg skal gerne indrømme, at jeg ikke har den ringeste ide om, hvad Bilde taler om. Hvilken form for humanistisk og historisk forskning drejer det sig om, hvor man igen anvender kategorierne sand og falsk? At man meningsfuldt og videnskabeligt uomgængeligt må tale om større eller mindre grader af plausibilitet, er indlysende; men er det ikke netop en indsigt, som videnskabsfilosofisk i vid udstrækning trækker på erkendelser, som hører netop socialkonstruktivisme og postmodernisme til? - og lad os så lige for præciseringens skyld pointere, at de to vel næppe kan tænkes uafhængigt af hinanden, skønt de heller ikke er identiske.

I en note klandrer Bilde også undertegnede for at dele Geert Hallbäcks "totale afvisning af projektets [dvs. rekonstruktionen af den historiske Jesus - AKP] teoretiske mulighed" (s. 80). Jeg ved ikke, hvor Bilde har sin viden fra; men det er i al fald ikke mit syn på sagen, og han har da heller ikke skriftligt belæg for sin påstand. Det er rigtigt, at jeg er meget skeptisk over for muligheden for på grundlag af de eksisterende kilder at rekonstruere den historiske Jesus; men det er selvsagt ikke det samme som en total afvisning af projektet. Jeg mener, der er flere ting, som med en høj grad af sandsynlighed kan hævdes at gå tilbage til den historiske Jesus. Det gælder eksempelvis hans korsfæstelse, hans forbindelse til Galilæa, hans relation til en bestemt gruppe mennesker (discipelskaren), hans forhold til Johannes Døber, etc. Det har jeg 
i øvrigt også i anmeldelser argumenteret for i dette tidsskrift. ${ }^{3}$ Jeg forfægter også det synspunkt, at en så solid forankret, historievidenskabelig drøftelse af den historiske Jesus er et gode, fordi den ikke mindst er et værn mod såvel religiøse som irreligiøse fantasters forestillinger om den historiske Jesus. Men når det så er sagt, tillader jeg mig også at forholde mig kritisk til en forskning, som bygger på for et historievidenskabeligt perspektiv ideologisk stærkt tendentiøse kilder. Det drøfter Bilde aldrig rigtigt og forstår det muligvis heller ikke, hvilket følgende citat tydeligt dokumenterer:

I modsætning til denne position (sc. at være skeptisk over for rekonstruktioner af den historiske Jesus), som ikke alene er ideologisk, men også teologisk apologetisk, fordi den tjener til at friholde den historiske Jesus for videnskabelig kritik, er jeg, som nævnt $\mathrm{i}$ kap. 2.2., overbevist om, at kildematerialet til Jesus ikke er dårligere og dermed vanskeligere at analysere end kildematerialet til andre historiske personer som fx Sokrates, Alexander Den Store og Caius Caligula, for ikke at tale om Retfærdighedens Lærer, Johannes Døber, Apollonios fra Tyana eller Simon Bar Kokhba, og alene af den grund vil historiske forskere blive ved med at forsøge at rekonstruere den historiske Jesus, uanset om de teologiske eksperter finder dette muligt eller relevant (s. 83).

Man fristes til at udbryde: Viel Geschrei und wenig Wolle. Der er tale om en besværgelse uden nuancer. Hvem er det fx, Bilde henviser til, som i dag har en stor interesse i at rekonstruere Retfærdighedens Lærer? Har vi ikke netop inden for Qumranforskningen de seneste 15 år kunnet iagttage samme bevægelse, som når det gælder forskningen i den historiske Jesus, nemlig en betydelig tilbageholdenhed, grænsende til skepsis og et langt større fokus rettet mod teksterne fortolket i lyset af deres historiske kommunikationssituation? Så meget desto mere, fordi den tidligere temmelig bastante rekonstruktion af Qumran med en tæt sammenhæng mellem ruinkompleks og tekstfund i de 11 huler efter 1994, hvor samtlige tekster blev tilgængelige, har måttet vige for betydelig flere nuanceringer og differentieringer. Og hvad med Sokrates-figuren? Rent bortset fra, at vi i forhold til Sokrates-skikkelsen har den store fordel, at der eksisterer tre af hinanden uafhængige skriftlige overleveringer, hvilket adskiller sig markant fra evangeliematerialet, ignorerer Bilde, at der i relation til denne forskning har været en tilsvarende diskussion om, i hvor høj grad det overhovedet er muligt på baggrund af det overleverede materiale at rekonstruere den historiske Sokrates - man kan blot tænke på Kierkegaards disputats, der allerede tog denne problemstilling op til drøftelse. Bilde nævner heller ikke, ej heller en passant, at ingen af de tekster, der i forhold til de øvrige figurer er overleveret, er skrevet ud fra den klare forudsætning, at den centrale skikkelse tilskrives guddommelig status (Apollonios fra Tyana er i den sammenhæng en særlig drøftelse værd). Har det slet

Se fx mine anmeldelser af Bart D. Ehrman, Jesus. En apokalyptisk profet, Religionsvidenskabeligt Tidsskrift 41, 2002, 97-100, og William Arnal, The Symbolic Jesus. Historical Scholarship, Judaism and the Construction of Contemporary Identity, Religionsvidenskabeligt Tidsskrift 48, 2006, 100-102. 
ikke betydning for den måde, Bilde driver historievidenskab på? Vi har fx hverken hos Aristofanes, Platon eller Xenofon beretninger om sokratiske mirakler. Det samme gælder i forhold til Retfærdighedens Lærer. Gør det slet ingen forskel? Det ville tjene Bilde til ære, hvis han argumenterede med nuancer og ikke så proklamatorisk, som hans udsagn fremstår. Bilde tilraner sig derigennem retorisk disciplinen historievidenskab, men i nuanceringens navn synes jeg, at det havde været mere rimeligt at skrive, at det drejer sig om en bestemt gren inden for en begivenhedshistorisk tradition, som de færreste i dag udøver på samme meget ligefremme måde som Bilde. Sagt på anden vis: Det er få, som i aktuel historieforskning bruger kilder så uproblematisk som beretninger, der kan anvendes til at rekonstruere en bagved liggende virkelighed. De fleste har i dag en betydelig større forståelse for den intrikate sammenhæng mellem kilder anvendt som beretning og som levning.

Selve bogens titel Hvor original var Jesus, der har en umiskendelig klang af en bedaget form for liberalteologi, forklares aldrig rigtigt, skønt den ægger til indsigelse fra et både historievidenskabeligt og alment human- og samfundsvidenskabeligt perspektiv. Hvad betyder originalitet i sammenhængen? Godt nok hævder Bilde på s. 299, at begrebet originalitet i bogens sammenhæng ikke skal ses som udtryk for en kategorial påstand om et nybrud. Der er således ikke tale om 'originalitet' i absolut forstand; men det ændrer ikke ved anvendelsen af et temmelig idiosynkratisk begreb, som heller ikke teoretisk præciseres. Ser man på den forskning i den historiske Jesus, som internationalt de seneste 25 år har sat dagsordenen, er det tankevækkende, hvordan man netop har bevæget sig væk fra det dissimilaritetskriterium, som prægede den tidligere Jesus-forskning. ${ }^{4}$ Her var tanken, at dersom man var i stand til at fremanalysere de punkter, hvori Jesus adskilte sig fra sin samtid, havde man fundet ind til kernen i den historiske Jesus. Der er gode grunde til, at man har gjort op med dette kriterium og bevæget sig i diametral modsat retning, hvor et kontekstualiseringskriterium i stedet er gjort udslagsgivende for forsøget på at rekonstruere en historisk plausibel Jesus-figur. Når Bilde selv skal forklare sin tale om Jesus' originalitet, betoner han, at:

Ved Jesus' eventuelle "originalitet" forstår jeg således vigtige vidnesbyrd i de overleverede kilders beretninger om Jesus' ord og gerninger, som - når de sammenlignes med andre kendte og beslægtede skikkelser primært i Jesus' samtid, dvs. i det jødiske Palæstina og det østlige middelhavsområde i perioden fra ca. 170 f.v.t. til 135 e.v.t., men dog med udblik til sammenlignelige skikkelser i andre geografiske områder og i andre epoker - kan betegnes som "ejendommelige" eller "enestående" for Jesus. Sådanne mulige originale træk skal formodentlig især søges i forbindelse med hans særlige projekt og de med dette projekt forbundne særlige religionsfænomenologiske roller og funktioner, som han selv og/eller hans tilhængere og modstandere tillagde ham (s. 28).

4 Se hertil Bart Ehrman, Jesus. En apokalyptisk profet, oversat af Anders Engberg-Pedersen, 2001. 
Her taler, så vidt jeg kan se, en romantiker og ikke en historiker. Bilde betoner selv længere fremme i bogen, hvordan han ikke i den hidtidige Jesus-forskning har kunnet finde "en systematisk og udtømmende undersøgelse af spørgsmålet om Jesus' originalitet" (s. 34). Det kunne der have været gode grunde til at overveje, for søgningen efter originalitet får ofte selvbekræftende karakter. I en cirkulær slutning finder man, hvad man allerede var tilbøjelig til at lede efter. Det siger ikke, som kritikken af liberalteologiens forsøg på at rekonstruere den historiske Jesus til fulde har dokumenteret, nødvendigvis særlig meget om genstanden for den historiske undersøgelse. Til gengæld er det afslørende for de ofte uerkendte interesser, der ligger bag undersøgelserne; men lad os se mere indgående på bogens argumentation.

Det første større kapitel to, som drøfter Jesus-forskningen fra ca. 1770 og frem til i dag, er noget springende i valg af forskere i den historiske Jesus. Det skyldes, at Bilde i kapitlet ikke alene vil tegne den internationale forskning, men også den danske. Det er meget fint; men det får undertiden en noget komisk karakter, når decideret lokale indslag skal parres med internationale. Mere problematisk er, synes jeg, at Bilde i forhold til den internationale drøftelse sammenstiller positioner, som måske nok i nogle henseender ligner hinanden, men som forskningshistorisk er indbyrdes meget forskellige. Det gælder fx tanken om Jesus som jøde, hvor Bilde uden videre kan etablere en traditionslinje, der strækker sig fra Reimarus over Johannes Weiss (et spring på over to hundrede år) videre over Albert Schweitzer og Julius Wellhausen og frem til Bultmann (s. 83). Mindre problematisk bliver det ikke, når også John $\mathrm{P}$. Meiers A Marginal Jew: Rethinking the Historical Jesus (vol. 1-4, 1991-2009) kan tages til indtægt for samme synspunkt. Forskellene disse forskere imellem i deres syn på den historiske Jesus er så betragteligt, at der skal mere end en særlig prokrustesseng til for at strække dem ud og skære dem til, så de kan tilpasses samme forskningshistoriske leje. Når nu Bilde i så stærke vendinger klandrer danske forskere, der - som han også selv - har baggrund i teologien, og i særlig grad dem, som skulle være inficeret af dialektisk teologi, kan man undre sig over, at Bilde spænder netop Bultmann for sin vogn. Hvordan hænger det sammen, at den dialektiske teologis mest betydningsfulde skikkelse gøres til fælle i Bildes projekt (se dog s. 48-50)?

Temmelig nonchalant afvises den overvejende nordamerikanske gruppe af bibelforskere, som inden for rammerne af det Jesus-seminar, som igennem en mangeårig periode har fundet sted i regi af Society of Biblical Literature, har forsøgt gennem tilbageskrivninger af navnlig Q-materialet ${ }^{5}$ at argumentere for en forståelse af Jesus som kynisk vandringsfilosof eller vismand, med, at “den igennem den sidste snes år [har] været udsat for så sønderlemmende kritik, at den blandt flertallet af nutidens førende Jesus-forskere ikke længere tages alvorligt" (s. 85 - noget mere forstående drøftes samme forskningsretning s. 125). For det første er det selvsagt ikke et argument. Vi er

Q (forkortelse for det tyske Quelle) betegner som bekendt den enten skriftligt eller mundtligt traderede kilde, som Matthæus- og Lukasevangeliet foruden den litterære afhængighed af Markusevangeliet ifølge tilhængere af to-kilde-hypotesen skulle have til fælles. 
vel endnu ikke kommet dertil, hvor videnskabelige diskussioner afgøres ved håndsoprækning. For det andet afhænger perspektivet i høj grad af, hvor man geografisk retter sit fokus. Jeg er ikke sikker på, at Bildes påstand ville få lige så klar opbakning i et nordamerikansk miljø, mens den utvivlsomt giver god mening i en tysk-dansk sammenhæng. Jeg deler selv i vid udstrækning Bildes kritik af Jesus-seminarets arbejde; men jeg synes ikke typen af fremført kritik er saglig. Der skal argumenter på bordet, hvis man vil afvise denne forskning, og også den fortjener anerkendelse for en række af de pointer, som Jesus-seminarets arbejdsgruppe gennem årene har fremført. Det har ikke mindst bidraget til en mere nuanceret forståelse af kulturelle, sociale og religiøse forskelle i Palæstina i slutningen af Anden Tempelperiode, ligesom det har været med til at føre den såkaldte jødedom-hellenisme-debat væsentligt videre.

I kap. 3 bevæger Bilde sig over til at drøfte forskellige tidligere tolkninger af Jesus' originalitet. I kapitlets første del lader han en sand kakofoni af forskellige stemmer komme til udtryk uden forsøg på at differentiere mellem dem. Her optræder nye som gamle fortolkere, nationale som internationale, katolske som protestantiske, jødiske som stærkt konservative repræsentanter for en protestantisk, kristen højrefløj. De indbyrdes meget forskellige stemmer, der gengives uden hensyntagen til deres argumentative sammenhæng, sammenfattes i tre pointer. For det første, at der gennem tiden er:

givet forbløffende mange og overraskende forskellige svar: Jesus' personlige forbundethed med den jødiske gud, Jahve, hans (deraf afledte) fuldmagt, hans radikalitet, hans enestående personlighed, hans etiske belæring og formaninger, hans kritik af sin egen tid(s - sic) jødedom og hans dermed forbundne spiritualisering og universalisering af jødedommen, hans frigørelsesvirksomhed og hans personlige etiske eksempel (s. 101).

For det andet hævdes det, "at adskillige af disse bestemmelser af Jesus' originalitet er generelle, brede og næsten indholdstomme" (ibid.); og for det tredje, at de to forudgående kendsgerninger gør det klart, "at det ikke er let at bestemme den historiske Jesus' originalitet" (ibid.). Ser man bort fra formuleringernes påfaldende liberalteologiske sprogdragt med en redundant betoning af Jesus' enestående personlighed og hans personlige etiske eksempel, virker denne harmoni over hidtidig Jesusforskning temmelig egensindig. Her fra fortsætter Bilde med at præsentere syv tematiske grupper, som han beskriver hidtidige bud på Jesus' originalitet inden for. Bilde burde i den sammenhæng have gjort det klart, at en række af de præsenterede forskere ville have sig betakket for at se deres synspunkter kategoriseret $\mathrm{i}$ forhold til et spørgsmål om den historiske Jesus' originalitet, som mange af dem ville have historievidenskabeligt begrundede vanskeligheder ved at forstå betydningen af. Først drøftes det traditionelle kristne svar, som efter sigende skulle være, at Jesus både var gud og menneske. Rent bortset fra at skildringen igen er malet med meget bred og noget dogmatiserende pensel drøfter Bilde slet ikke, hvem blandt kirkefædrene han 
har i tankerne. Vi får blot at vide, at dette er det traditionelle kristne svar på spørgsmålet om Jesus' originalitet (s. 102). Derpå videre til et afsnit om at Jesus' originalitet skulle bestå i hans etik, hvor Bilde medgiver, at denne tanke "ikke er uden grundlag" (s. 113). Om lignelserne gælder omvendt, at de "hverken som genre eller sprogform eller de øvrige foreslåede formelle kendetegn på 'Jesus' egen stemme' har kunnet holde til den efterfølgende kritiske efterprøvelse, hvorfor de må opgives" som udtryk for Jesus' originalitet. Denne konklusion ændrer dog ikke ved, hævder Bilde, "at man også må opgive sansen for og anerkendelsen af, at en del af Jesus' lignelser er umiddelbart tiltalende, kunstnerisk tiltrækkende og etisk appellerende" (s. 117). Ja, det er selvsagt muligt og hvad har det med historievidenskab at gøre? Det er tankevækkende for disse afsnit og delvist karakteristisk for bogen som helhed, at vi stort set ikke finder eksempler på ordentlig og grundig eksegese, hvor de græske tekster udlægges med inddragelse af paralleller og bevågenhed om det specifikke i den enkelte tekst. I stedet for henvises til andre forskere og deres arbejder, og på det grundlag fælder bogen dom, men argumentationen forløber uden henvisning og belæg i de tekster, bogen foregiver at ville sige noget om. Alternativt henvises løselig til teksterne, men uden dybdeborende eksegese, idet teksterne læses som punktnedslag uden sans for deres argumentative og narrative sammenhæng. Det gælder her som i Torquato Tasso: Man merkt die Absicht und wird verstimmt.

I det følgende underafsnit bevæger Bilde sig over til en drøftelse af befrielse eller frigørelse, der går som en rød tråd gennem Jesus-overleveringen. Igen kunne man have ønsket sig en præcisering, for der er også i denne sammenhæng forskel på evangelierne, hvor ikke mindst Lukas indtager en særstilling (særligt økonomisk frigørelse); men på ny udjævnes forskelle til en generel tanke om Jesus som frigører. Bilde hævder her, at det gælder om Jesus som både 'jordisk' og 'mytologisk' befrier, at der findes mange paralleller til disse sider af Jesus' virke, hvorfor han på dette grundlag ikke ser sig i stand til at "fælde en entydig dom om spørgsmålet om Jesus' originalitet" (s. 122). Igen er det tydeligt, at det er et liberalteologisk dissimilaritetskriterium, der ligger bag konklusionen; men bliver Jesus virkelig mindre original, hvis man nu skulle anvende Bildes terminologi, fordi han ligner andre figurer i sin samtid? Det tror jeg ikke; men det beror på en anden forståelse af kultur og historisk nybrud end den, Bilde abonnerer på.

Heller ikke i det næste underafsnit om det nært forestående gudsrige finder Bilde belæg for en særlig originalitet hos Jesus (s. 122-28). Anderledes ser det ud med beretningerne om helbredelser og andre undergerninger, hvor Bilde mener, at der " $\mathrm{i}$ dag [kan] tales om en vis konsensus i Jesus-forskningen om, at Jesus' eskatologisk fortolkede dæmonuddrivelser og helbredelser var et væsentligt og karakteristisk træk hos den historiske Jesus, et træk, der måske også kan tolkes som et vidnesbyrd om Jesus' særlige originalitet" (s. 132). Jeg skal indrømme, at jeg ikke forstår, hvad Bilde mener. Enten skriver han bevidst misforståeligt eller også taler han med uld i mund. Som historiker går man ud fra den grundlæggende videnskabsteoretiske 
præmis, at skønt fortolkningerne af verden er mange og adskiller sig i tid og rum, er verden en. Hvis mennesker ikke kan gå på vandet i dag, helbrede syge med ordmagi eller opvække døde til levende, kunne de det heller ikke i antikken. Fortolkningsrummet flytter sig løbende, men ikke det fysiske univers, i hvilket vi befinder os. Jeg forstår ganske enkelt ikke, hvordan Bilde som historiker pludselig kan acceptere en forandret verden, i hvilken mirakler ikke som fortolkninger, men som fysiske begivenheder skulle kunne finde sted. Det ligner for mig en form for primitivisme, hvor man tilskriver fortidige verdener og mennesker ting, som ingen i dag ville abonnere på. Jeg mener faktisk, det er en pointe, at Jesus allerede i evangelierne er fremstillet med en række kontraintuitive træk som fx evnen til at udføre mirakler.

Det sidste underafsnit vedrører Jesus' autoritet og status. Også her synes jeg, der mangler differentieringer i forhold til teksthenvisning. Fx siges det om Jesus med henvisning til Gal 4,4, at han ifølge den paulinsk-johannæiske tolkning forstås som et præeksistent guddommeligt væsen (s. 133); men Bilde må da vide, at der siden begyndelsen af 1980'erne har været en lang tradition for at hævde, at vi ikke hos Paulus finder en præeksistenstanke (heller ikke i Fil 2, 5-11, uanset om teksten har førpaulinsk karakter eller ej). ${ }^{6}$ Mere problematisk er, at vi også i dette afsnit finder en række eksempler på det, man historievidenskabeligt normalt omtaler som psykologiseringer (som yderligere markante eksempler, se s. 163f.170.172.182.185). Man kan ikke slutte fra en tekst til, hvad der foregår oppe i hovedet på forfatteren. Endnu mindre kan man selvsagt slutte fra en fortalt skikkelse i en tekst til, hvad der måtte være foregået i hovedet på den pågældende skikkelses empiriske korrelat. Ikke desto mindre mener Bilde på baggrund af ganske få kilder og nu med ingen ringere end den dialektisk-teologiske og let pietistiske Ernst Käsemann som hjemmelsmand at kunne hævde, at "den historiske Jesus synes således at have tillagt sig selv en helt usædvanlig funktion, rolle og status, som han formodentlig mente var tildelt ham af Jahve selv" (s. 138). En ting er på baggrund af evangelieteksterne at ville sige noget om den historiske Jesus. Dér kan vi diskutere, hvor langt man kan eller skal gå; men jeg synes, Bilde går betydeligt videre, når han på grundlag af fortalte figurer i teksterne vil kunne sige noget om, hvad de historiske skikkelser rent faktisk har tænkt.

Resultaterne i disse fælles underafsnit fører til den generelle konklusion, at en kombination af Jesus' eskatologiske gudsrigeproklamation og hans virke som undergører kan hævdes at være enestående, ligesom også en del af hans etiske belæring, som der ikke umiddelbart ifølge Bilde findes paralleller til, og dertil hans virke som historiefortæller (s. 140). Disse træk fører så yderligere til den konklusion, at ikke alene Jesus' tilhængere, men også Jesus selv, særligt i slutningen af hans virke, har

\footnotetext{
Se fx James D. G. Dunn, Christology in the Making. A New Testament Inquiry into the Origins of the Doctrine of the Incarnation, Westminster Press, Philadelphia 1980, og Karl-Josef Kuschels mere populært skrevne, men ganske udmærkede bog, Geboren vor aller Zeit? Der Streit um Christi Ursprung, Patmos Verlag, München 1990.
} 
opfattet ham som Jahves udvalgte og salvede talsmand, som den forjættede eskatologiske profet (Moses eller Elias) eller den forudsagte Messias (ibid.).

Med kap. 4 bevæger Bilde sig over til at drøfte Jesus' eskatologiske projekt i forlængelse af de to forudgående kapitler. Hans lægger sig i forlængelse af de seneste 30 års internationale mainstream forskning, som netop har betonet nødvendigheden af at se den historiske Jesus som uomgængelig del af jødedommen i slutningen af Anden Tempelperiode (hovednavne i denne sammenhæng er E.P. Sanders, John P. Meier, Paula Frederiksen, Bart D. Ehrman og Dale Allison). Programmatisk formuleres det undertiden, at Jesus' projekt ikke var at gøre op med jødedommen, hvilket i sig selv er en pudsig formulering, da den forudsætter en tredje-ordens bevidsthed hos Jesus, men i stedet at reformere sin tids jødedom. Det er nok mere præcist at pointere, at det drejer sig om navnlig et opgør med en farisæisk fortolkning af jødedommen; men lad det nu være. Bilde går imidlertid et - psykologiserende - skridt videre end det meste forskning, når han yderligere hævder, at Jesus muligvis opfattede sig selv som "den eskatologiske profet, måske som profeten, som forudsiges i 5 Mos 18, 15" (s. 141). Det kan selvfølgelig tænkes; men det ligger uden for det historievidenskabeligt mulige at falsificere eller verificere denne påstand. Det grundlæggende synspunkt i kapitlet er, at den historiske Jesus skal forstås som en eskatologisk messiasprætendent, hvis mål var en genrejsning af det israelske tolvstammefolk - det bliver aldrig helt klart hos Bilde, om han tænker dette inden for rammerne af en lokativisk eller en utopisk religionsform; men jeg antager det første. Bilde understreger også, at Jesus hverken var saddukæer, essæer, farisæer eller zelot, men derimod “en apokalyptisk tænkende, eskatologisk restaurationsjødisk profet og messiasprætendent" (s. 190), hvilket giver god mening, når blot det tilføjes, at Jesus i denne forståelse øjensynlig har set sig mest truet eller udfordret af farisæerne, eftersom det er dem, som vi finder langt de fleste stridssamtaler med i den synoptiske tradition. En pointe, som Bilde med fordel kunne have taget til sig fra religionssociologien, men som ikke er udfoldet hos ham.

I det afsluttende meget omfattende kapitel går Bilde videre til en sammenligning af den rekonstruerede historiske Jesus - dels med andre skikkelser fra datiden, dels med senere sammenlignelige figurer, hvor det $x$, sammenligningen foretages $i$ forhold til, udgøres af en messiansk eskatologisk forståelse. Bilde er i sin forståelse af muligheden for både at rekonstruere og for at identificere Retfærdighedens Lærer betydelig mere positiv, end jeg er. Han bygger i den sammenhæng på værker af Michael Wise og Israel Knohl, som imidlertid ikke alene er blevet godt og grundigt kritiseret i Qumran-forskningen, men som også går forud for det store skel i begyndelsen af 1990'erne, hvor samtlige tekster fra Hule 4 blev gjort tilgængelige. Det har i Qumran-sammenhæng ført til betydelig større skepsis over for den klassiske essæertese, hvilket Bilde ikke nævner med et ord. Bilde er efter min mening på mere sikker grund, når han sammenligner den rekonstruerede historiske Jesus med forskellige profetskikkelser omtalt hos Josefus. Det er i den forbindelse også oplagt, som Bilde 
gør, at se på parallellerne til Johannes Døber, om hvem vi med en betydelig grad af historisk vished ved, at Jesus en periode stod i forbindelse med. Men igen går Bilde meget langt, og efter min mening betydeligt længere end kilderne kan bære, når han både vil have Retfærdighedens Lærer, Johannes Døber og Jesus til at gå op i en højere enhed. Følgende citat har nærmest karakter af tvangseksegese, for der er intet i 1 QpHab 2, 1-8, som lader antyde, at kredsen bag Habakukpesheren skulle have vaklet "i troen på Retfærdighedens Lærer":

Også qumranitterne var overbevist om at leve i opfyldelsens tid. De delte den grundlæggende tidlige jødiske tro på, at løfterne om Israels genrejsning i messiansk herlighed stod umiddelbart foran deres definitive virkeliggørelse. Derfor ramtes Qumransamfundet lige så hårdt som senere Johannes Døber-kredsen og Jesus-bevægelsen, da de ventede eskatologiske begivenheder alligevel ikke indtraf. Det var måske netop denne smertelige erfaring, der førte til den vaklen i troen på Retfærdighedens Lærer, der omtales i 1 QpHab 2, 1-8 (s. 237).

1QpHab 2, 1-8 kredser om, at endetiden trækker ud, og i den sammenhæng forsøger teksten at styrke de intenderede modtagere i overbevisningen om, at den fortsatte venten ikke er et problem, men snarere en bekræftelse af tekstens forståelse. Der står efter min mening intet i teksten om, at modtagerkredsen skulle "vakle i troen på Retfærdighedens Lærer ."Det er ganske enkelt en ' kristen' indlæsning farvet af den særlige rolle, Jesus tillægges i Kristusbevægelsen. Hvordan Bilde også i ramme alvor kan hævde, at den historiske Johannes Døber måske opfattede sig selv som den tilbagevendte Elias, er også uklart for mig (s. 241). Jeg synes ikke, at sådanne former for psykologisering er forenelig med god historievidenskab. Mindre grotesk bliver det ikke i forhold til, hvad kildematerialet kan bære, når Bilde om Jesus hævder, at han på et tidspunkt blev uenig med eller skuffet over Døberens projekt og derfor brød med ham: "Personligt hælder jeg til den anskuelse, at dette brud skete som følge af en "parusiudeblivelse": Den af Johannes proklamerede nært forestående dom kom ikke - og hvad så? Det kan måske tænkes, at Jesus brød med Johannes-kredsen på grundlag af en uenighed om tolkningen af denne parusiudeblivelse?" (s. 245). Det er selvsagt ikke utænkeligt; men det er spekulation, når ikke der kan fremføres dokumentation for sagen.

Der er en anden ting, som har undret mig en del i Bildes gennemgang af paralleller mellem Jesus og forskellige profetskikkelser omtalt hos Josefus og Bildes efterfølgende inddragelse af Simon Bar Kokhba og Rabbi Akiba. Et af de elementer, som jeg anser for historisk troværdig i overleveringen, er det forhold, at Jesus' nærmeste disciple tilsyneladende ikke led overlast. Det burde efter min opfattelse problematisere en rekonstruktion af den historiske Jesus i lyset af de militante profetfigurer, man møder hos Josefus, og i Bar Kokhba. Snarere bringer det Jesus tættere på en figur som Jesus Annaniassøn, men det er ikke et tema, Bilde for alvor opholder sig ved. I kapitlets sidste del drøfter Bilde senere tiders beslægtede jødiske skikkelser. 
Ideen er god og har også vundet en vis udbredelse i Baumgarten-skolen, ikke mindst hos Eyal Regev; men jeg synes ikke, at Bilde for alvor får den udnyttet. Sammenligningerne bliver noget overfladiske og lapidariske. Det gælder fx de korte afsnit om Sabbatai Zvi og Menachem Schneersohn (s. 275-78). Efter min mening er Bilde også for påvirket af det traditionelle syn på jødedommen, at både zeloter, essæere og saddukæere forsvandt ud af jødedommen i forlængelse af templets fald i 70 e.v.t. Her burde ikke mindst Martin Goodmans forskning fra de seneste år have været inddraget. ${ }^{7}$ Bilde nævner også en passant enkelte græsk-romerske figurer, som det er meningsfuldt at sammenligne den rekonstruerede historiske Jesus med, men igen er det ikke særligt dybdeborende. Konklusionen på kapitlet er da også, at de umiddelbart største ligheder med Jesus skal søges hos Johannes Døber og rækken af skikkelser, som Josefus berettet om, og endelig hos Retfærdighedens Lærer. Mens jeg er usikker på det sidste og $\mathrm{i}$ forhold til Josefus ville foretrække at nuancere billedet på en måde, som fremhæver ligheden mellem den historiske Jesus den pacifistiske Jesus Annaniassøn frem for andre mere militante figurer, er jeg et langt stykke af vejen enig med Bilde. Men jeg finder det stærkt overdrevent, når han går et skridt videre og hævder, at foruden Jesus og Bar Kokhba "kan [det] ikke udelukkes, at også hasmonæerfyrsten Simon, Judas Galilæer, Theudas, Den Ægyptiske Profet og flere andre optrådte og/eller af deres tilhængere blev anerkendt som messiasprætendenter" (s. 293). Det kan på ny selvsagt ikke udelukkes, men det er fra et historievidenskabeligt perspektiv gisninger og som sådan udtryk for dårlig historievidenskab.

Tilsvarende peger Bilde på flere forskelle mellem Jesus og disse personer, som han samler i syv punkter: (1) For Johannes Døber, Jesus og Retfærdighedens Lærer gælder, at de alene som kvietister efterstræbte Israels genrejsning, som de i et apokalyptisk verdensbillede var overbevist om ville indtræde i tidens fylde; (2) fælles for dem var også deres forkyndelse om, at tiden nu var inde, skønt helbredelser, dæmonuddrivelser og andre undere var specifik for Jesus; (3) sammenstillingen af præsentisk eskatologi og undere er unik for Jesus; (4) Jesus' relation til Toraen var i sammenligning med de øvrige skikkelser særegen; (5) alene Jesus lagde vægt på, at gudsriget også var rettet mod de fortabte får af Israels hus; (6) kun Jesus og sandsynligvis Retfærdighedens Lærer forudså og forudsagde deres egen død; (7) kun Jesus udpegede 12 tilhængere som ledere af det kommende genrejste Israel (s. 294f.). Jeg kan ikke her gå mere i dybden med de enkelte punkter, men vil nøjes med at pege på den allerede fremførte kritik af flere af dem. For det første synes jeg, at Bilde under punkt fire får sammenblandet den historiske Jesus med de forskellige evangelieforfatteres forskellige syn på loven, ligesom han heller ikke tilbundsgående overvejer, om dette punkt er så særegent for Jesus eller om ikke snarere, vi her har en større viden, fordi konflikten mellem Jesus-tilhængere og andre jødiske grupper (særligt

Se fx M. Goodman, "Modelling the "Parting of the Ways"," in: Adam H. Becker \& Annette Yoshiko Reed, eds., The Ways that Never Parted. Jews and Christians in Late Antiquity and the Early Middle Ages, Tübingen, Mohr-Siebeck 2003, 119-130. 
farisæerne) først og fremmest drejede sig om lovfortolkning .Flere af de andre punkter kan man også finde paralleller til i datidig jødedom, hvis man ikke reducerer spørgsmålet til at være personbåret; men først og fremmest finder jeg det problematisk, at andre former for jødedom skal rettes til i et leje, som stammer fra en bestemt fortolkning af tidlig kristendom.

Bogens afsluttende kapitel sammenfatter de forudgående kapitlers hovedpointer på en klar og overskuelig måde samt redegør for de grundlæggende begreber 'sammenligning' og 'originalitet'. Det sidste kunne man, som allerede anført, godt have ønsket sig i bogens indledning, men selv med afslutningskapitlets præciseringer fremstår brugen af navnlig originalitetsbegrebet fortsat problematisk. Ikke overraskende lægger Bilde stor vægt på, at han først og fremmest opfatter Jesus som det i historien bedst dokumenterede udtryk for den videre religionsfænomenologiske genus eskatologisk profet og messiasprætendent (s. 305).

Som det er fremgået af denne artikel, er jeg ganske kritisk over for Bildes bog. Jeg synes, at Bilde på flere punkter toner frem som repræsentant for en historievidenskab, som jeg har vanskeligt ved at se, at han har belæg for. Det gælder ikke mindst synet på undere. Bildes betoning af en originalitetstanke er også efter min mening ikke alene filosofisk naiv men også historievidenskabelig from, også selvom han afslutningsvis pointerer, at den ikke er tænkt i kategorial forstand. Dertil kommer, at Bildes behov for at iscenesætte sig selv som historievidenskabelig dragedræber af teologisk-apologetiske fortolkninger i længden bliver ulidelig. Det er patetisk at læse en bog, som i så høj grad har brug for en konspirationsteori til at underbygge sit ærinde; men jeg kan selvsagt ikke udelukke, at Bilde har ret. Det kan faktisk tænkes, at den samlede danske forskning - med undtagelse af Bilde og enkelte repræsentanter fra den kirkelige højrefløj - afholder sig fra at rekonstruere den historiske Jesus som led i en teologisk konspiration. Det er sågar muligt, at Bilde har afsløret sammensværgelsen; men det kunne måske også overvejes, at mange historievidenskabeligt arbejdende forskere afstår fra at begive sig ud i alt for omfattende rekonstruktionsforsøg, fordi de har forstået, at kilderne har et sådant præg, at det vil antage karakter af spekulation og selvspejling at gå for langt ad denne vej.

Professor Anders Klostergaard Petersen Religionsvidenskab, Aarhus Universitet 